\title{
ROMANIAN ACHIEVEMENTS IN PETROLEUM INDUSTRY
}

\author{
Maria Stoicescu $^{1}$, Eugen Mihail Ionescu²
}

\begin{abstract}
Petroleum has been and still remains, in equal measure, a friend and an enemy to humanity: a friend for its use in numerous applications over the years, from the lubrication of cart axles to jet fuel; an enemy for creating permanent conflicts between countries, leading to a global conflagration. This layout has perpetuated for over two millennia, until today.

The problem of petroleum has a multitude of aspects: economic, political, financial, social, military, legislative and, last but not least, scientific and technical. It has taken a share of sacrifices, which may not be overlooked, to be rightfully called "black gold." Subject to continuous development, petroleum is still indispensable to our quotidian life, although attempts have been made to replace it with alternative energy sources due to its negative effects on the planet, which are increasingly visible.

The present state of petroleum industry is the result of a continuous labor of many generations of researchers, professors, engineers, technicians, foremen, and workers, especially from petroleum producing countries. Romania is one of the first petroleum producers and ranked first in Europe and among the first nations worldwide until the end of the $19^{\text {th }}$ century. During the $20^{\text {th }}$ century, a large number of oil and gas reservoirs were discovered in many countries on all continents; even today Romania still remains an important producer with encouraging perspectives.

Romanian contributions to the progress of petroleum industry are noticeable, being appreciated and implemented by the major companies worldwide. This work intends to present just several of these contributions, some of which are highlighted and highly regarded.
\end{abstract}

UDC Classification: 94:355.823 2(498) (075), DOI: http://dx.doi.org/10.12955/cbup.v2.456

Keywords: petroleum, black oil, oil production, oil well, oil processing, petrochemistry

\section{Introduction}

Petroleum has been a key natural resource in the world. Used as an energy source and as a raw material for the petrochemical industry, it plays a major role in the economy of each country.

In Romania, crude oil has been discovered and used, on small scale, from the most ancient of times. Widening its field of use, with growing demand for crude oil, natural gas, petroleum distillates and petrochemical products during the last century, has led to the intensification of exploration, production, transport, storage, processing, and related activities.

Romania is one of the first countries in which oil production and processing have become industrial activities. For this reason, the Romanians are recognized for exceptional scientific and technical achievements in this field.

\section{Petroleum in Romania since antiquity until 1857}

Archeological evidence on petroleum far back in the universal antiquity is quite numerous. The permanent fires fed by natural gas or oil emerging on soil surface were considered by ancient people as "holy fires." The first documents that mentioned petroleum were written by Herodotus $\left(5^{\text {th }}\right.$ century BC); Vitruvius, Diodorus of Sicily, and Strabo ( $1^{\text {st }}$ century BC); Pedanius Dioscorides and Pliny the Elder $\left(1^{\text {st }}\right.$ century AD); Plutarch $\left(2^{\text {nd }}\right.$ century AD). They also indicated the use of oil as grout for sealing material for ships and pipes, bond, lubricant, fuel for lighting and heating, weapon, remedy for human and animal diseases, etc.

Roman scholars mentioned the permanent fires from Lopătari (Buzău County, Romania) in the $1^{\text {st }}$ century AD (Gheorghiu, Neculau, Ionescu-Balea, \& Ştefănescu, 1972).

\footnotetext{
${ }^{1}$ Maria Stoicescu, Petroleum-Gas University of Ploiesti, Romania, stoicescu.maria@yahoo.com

${ }^{2}$ Eugen Mihail Ionescu, Petroleum-Gas University of Ploiesti, Romania, ionescu_em@yahoo.com
} 
Although no local documents were available until the $15^{\text {th }}$ century, archeological findings (pottery and jewels with oil or tar traces) proved that oil had been used on the present Romanian territory as far back as the $3^{\text {rd }}$ century AD.

The first national documents, which mentioned the black oil dated from October $4^{\text {th }}, 1440$ (Moldavia) and from November $22^{\text {nd }}, 1517$ (Wallachia). Afterward, numerous official acts were emitted concerning oil bearing and producing estates (Gheorghiu et al., 1972; Ivănuş, Ştefănescu, Stirimin, Mocuţa, \& Coloja, 2004).

Old Romanian documents designated oil as "păcură“ (black oil), a word which may be derived either from Latin word "pecoraris" (shepherd) or from another Latin term "picula" (drop). Another word for oil was later introduced "ţiţei" from the Latin "titia" (whey) (Giurescu, 1969).

Foreign travelers who visited the Romanian Principalities in the early $16^{\text {th }}$ century (Francesco Mattaro in 1523 and Francesco Della Vale in 1534) wrote about the "dark wax" used by locals for making candles (Popovici, 1957; Pop, 1961). At the end of the $16^{\text {th }}$ century, other travelers (Giovanni Botero, Jacques Bongras, Claudio Tolomeo, etc.) mentioned the local underground resources, including black oil. The black oil appeared in foreign documents more and more frequently in the $17^{\text {th }}$ and $18^{\text {th }}$ centuries (Marcus Bandinius, Bacsich, Roche, Nagny, Carra, Stamaty, Saint-Cyr, Gaudin, Ledoux, etc.) (Ionescu-Balea \& Ştefănescu, 1977).

The first work demonstrating a scientific approach of Romanian petroleum resources was "Descriptio Moldaviae," written by the Moldavian prince Dimitrie Cantemir in 1714.

Early oil producing systems were simple. Sometimes, oil from shallow reservoirs naturally emerged at the surface and associated with spring water. The oil was collected by locals from water surface (Lucăceşti, Moineşti, Teleajen, and Prahova valleys). In other cases, bituminous sands were swept with hot water (Prahova County) or small pits were dug near the oil buttes. When these shallow pits became wider, they were called "baths."

In time, the pits increased in depth (20 m and more) and had to be consolidated. The oil pits dug in Wallachia had a square cross-section and were stabilized with timber planks, while the ones from Moldavia, where the rocks were tougher, were supported by wickers.

The work above the top of the reservoir was relatively easy. The workers and their tools (spades, pickers, pails - all with short handles) would climb down with a rope harness on a manually actuated winch and the cuttings were lifted in the same manner.

The work became more difficult and dangerous when the reservoir top was reached, because of the gas emanations. The primitive aeration was done by moving up and down a wisp of branches tied on a rope, but this method was ineffective and workers suffered frequent asphyxiations. A solution for reducing gas emanations was to dig pits during the winter, when weather was cold and snow could be thrown inside. Then, air was pumped from the surface with bellows and sent to the bottom of the pit by pipes. An alternative method was the use of vacuum ventilators.

Lighting of pit bottom was done using mirrors, torches, candles, miner's lamps, or petroleum lamps. When hydrocarbon emanations appeared, frequent explosions with severe consequences would occur. Other accidents also occurred from collapse of pit walls, suffocation, and exhaustive work.

After the pit was completed, the oil was brought to the surface with wooden pails or skin bags attached to the winch rope. The manual winch was replaced, when pits depth increased, with a vertical-axle winch, driven by a horse, called "hecna."

Count Demidov, a Russian industrialist, diplomat and arts patron, who organized a scientific expedition whose itinerary included the Romanian Principalities, wrote in 1837 that oil was produced in Wallachia from several fields, the most important being situated in Păcureţi (Demidov \& Raffet, 
1853). The oil was loaded into wooden barrels and transported to Transylvania and to the Danubian ports, before being exported. Previous documents showed that Romanian crude oil was being exported through Danubian ports since 1780 (Romanian National Committee of World Energy Council, 2013).

It should be noted that, during the early years of the $19^{\text {th }}$ century, oil was also processed through primitive distillation procedures. The first oil distilleries in the world were built in Caucasus (1823), Galicia (1826), and England (1838). In Romania, the oil distillery built by N. Choss in Lucăceşti in 1840 was followed by the ones owned by Heimsohn (1844, Valea Arinilor) and in Nicolau (1853, Covasna). All these distilleries were producing kerosene used in lamps for lighting.

\section{Romanian Petroleum Industry after 1857}

During this period, the demand of kerosene was increasing, leading to the emergence of a real petroleum industry by discovery of new reservoirs and construction of processing facilities.

The year 1857 is considered as the official beginning of the Romanian petroleum industry because Romania (The United Principalities) was witnessed as the world's first in three exceptional events:

1. the first country in the world to be officially registered in the statistics with a crude oil production of 275 tons;

2. the first operating oil refinery in the world, built by the Mehedinţeanu brothers, in Ploieşti;

3. Bucharest, the capital city of Romania, became the first city in the world to have street lighting with kerosene.

On August 29, 1859, the drilling rig, designed by Edward Drake, drilled a 23-meter-deep oil well in Titusville, Pennsylvania, USA. That same year, in Romania, oil pits of more than 200 meters depth were manually dug by workers, unbeknownst in the history. The deepest manually dug pits were in Băicoi (240 m), Lucăceşti (250 m), Matiţa (268 m), and Breaza (320 m) (Boncu, 1971).

In 1861, the first Romanian mechanically-drilled well was accomplished in Mosoarele (Bacău County) up to a depth of 150 meters. Nevertheless, by the end of the $19^{\text {th }}$ century, most of the domestic oil production continued to be obtained from operating manually dug pits.

In 1862, Romania produced 3,226 tons of oil; one year later, there were 58 refineries and distilleries (Boncu, 1971). Both crude oil and kerosene were exported in Austria, Turkey, Great Britain, and France.

In 1893 , there were 1,893 pits (1,215 active) and 134 wells ( 71 active). After 1897 , however, the pits were rapidly replaced by wells dug with drilling rigs at depths of up to 900 meters, so that, in 1906, there were eight times more active wells than active pits.

Until the end of the $19^{\text {th }}$ century, oil production substantially increased $(11,690$ tons in $1870,15,900$ tons in $1880,53,000$ tons in 1890 , and 250,000 tons in 1900). Romanian statistics indicated 87 refineries in 1897 (40 of them were in Prahova County alone) (Ivănuş et al., 2004).

The scientific research in petroleum geology started at the Bucharest and Iasi universities under the leadership of the famous professors, Grigore Cobălcescu and Gregoriu Ştefănescu. In 1887, Gr. Cobălcescu wrote the first geological work in Romania, one of the world's first books of its kind. In 1898, Gr. Ştefănescu edited the first geological map of Romania at a 1:2,000,000 scale (Mircea, 1968).

During the first half of the $20^{\text {th }}$ century, the most important personality in petroleum geology was Ludovic Mrazek.

The foreign capital penetrated into the Romanian petroleum industry after the approval of the first Mining Law in 1895. The most important companies established before World War I were Steaua 
Română (1895), Româno-Americana (subsidiary of Standard Oil, 1904), Vega (Deutsche Bank, 1904), and Astra (Royal Dutch Shell, 1908) (Ştefănescu, 1998).

In 1914, the private capital invested in Romanian petroleum industry amounted to 403.6 million leigold (Răvaş, 1957) and was divided as shown in Figure 1 (Buzatu, 1981).

After the invention of Otto and Diesel engines, new petroleum products, gasoline and diesel fuel, were in demand.

Crude oil and oil residues were used as fuels for the steam boilers of steamers and steam engines. Romania was one of the first countries in the world to use oil residues as boiler fuel (since 1902).

In 1900, the first petroleum journal in Europe appeared "Monitorul de Petrol Român" [the Romanian Petroleum Monitor], which came out bimonthly and was bilingual (Romanian and French).

The Petroleum Commission was established in 1903 with the objectives, among others, of creating the inventory of petroliferous areas and improving drilling techniques. In 1905, the first geological map ranking Romanian oil areas by their producing potential was issued.

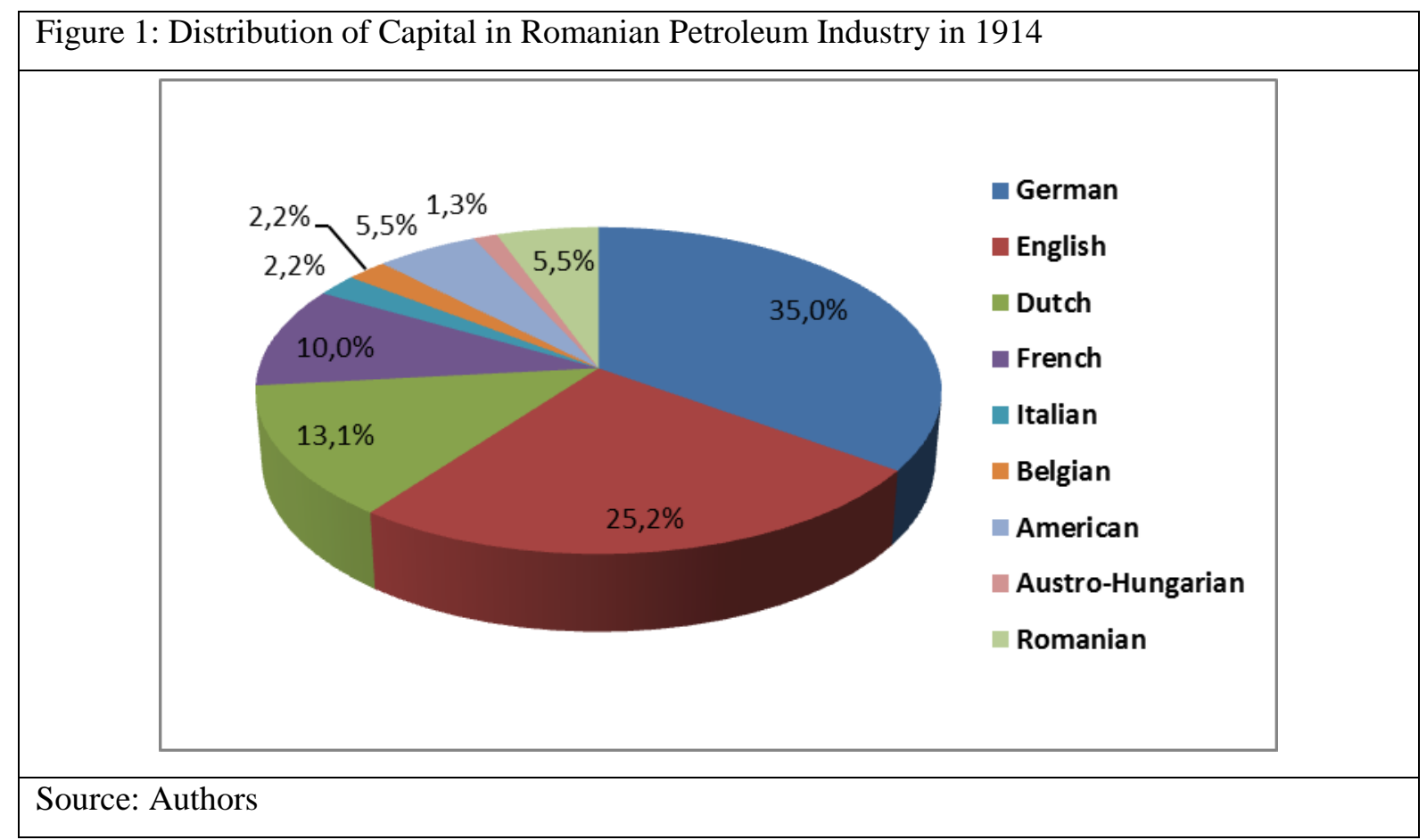

Technical papers having a high scientific level were written by Romanian engineers and scientists starting from the early $20^{\text {th }}$ century. Among numerous authors, we shall note V. Tacit, I. Tănăsescu, C. Hoisescu, N. Fisher, A, Saligny, D. Hurmuzescu, and C. Istrati.

Romanian engineers also patented techniques and devices used in petroleum exploration, drilling, production, processing, and petroleum products use: V. Tacit: bailing device for Canadian drilling (1903); G. Vasilescu: atomizer for burning fuel oil in boilers (1908); L. Edeleanu: Method for selective distillation using liquid sulfur dioxide (1908); A. Beldiman: drilling system with bottom-hole engine (1910); V. Tacit and V. Puşcariu: hydraulic valve (1912); P. Oteleşteanu: Romanian system of dry rotary drilling for oil (1921); E. Mărdărescu: rotary drilling system (1925); A. Drăgănescu: singlecasing well construction (1930); I. Basgan: Method for increased efficiency and improved rotary drilling by percussive rotations and by hydrodynamic pressure absorption (1934); I. Basgan: Rotary equipment for drilling wells (1937) (Bălan, 1979). 
In 1904, the world's first school for drilling foremen was established in Câmpina, Prahova County. Romanian specialists took part in all international petroleum conferences and their remarkable contributions in all aspects of the petroleum industry development were widely appreciated.

The first International Petroleum Congress took place in Paris (1900) and the second in Liège (1905), where the Romanian delegation propounded to organize the next congress in Romania. The proposal was accepted: in 1907, the $3^{\text {rd }}$ International Petroleum Congress was held in Bucharest. Its organization was unanimously appreciated and constituted the model for the first World Petroleum Congress in London in 1933.

One of the first maritime oil terminals in the world was put in place at Constanţa harbor. In 1914, it was equipped with 3,915 railroad tankers, loading/unloading platforms, pumping systems, oil storage tanks, etc. $90 \%$ of the exported Romanian oil in 1912 was handled at Constanţa oil terminal.

At the same time, a long distance pipeline project between Băicoi and Constanţa was launched, but the pipeline was constructed only after the World War I.

In 1909, the International Commission for Unification of Analysis Methods was established (headquartered in London), which had Romanian specialists as its members.

In 1915, in Romania, there were 42 oil companies, 56 oil refineries, 1,334 kilometers of oil pipelines, and an oil storage capacity of nearly 200,000 cubic meters. The amount of oil and petroleum products exported was 129.1 thousand tons.

During World War I, the Romanian petroleum industry faced some formidable losses; 1,677 oil wells, 827,000 tons of petroleum products, numerous refineries, storage reservoirs, pipelines, etc., were destroyed or self-destructed. The total losses were expressed as over 20 million Sterling Pounds, a significant amount at that time.

In 1924, the oil production, the refining capacity, the domestic consumption, and the export reached their pre-war levels. The recovery of the Romanian petroleum industry after World War I lasted for 6 years.

The Steaua Română oil refinery, established in 1897, once the biggest European refinery, still remained in operation during the 1930s, as the highest in capacity and the most modern in Romania.

In 1931, Romania implemented, as a world premiere, the electric log as a tool for well investigation, basing on applied geophysics.

In 1936, a modern refinery was established in Brazi, near Ploieşti, with the exclusive contribution of Romanian specialists and business people. It is worth noting that, during the inter-war period, the refining capacity was significantly increased from 1.65 million tons in 1924 to 10.6 million tons in 1939. In addition, new or upgraded oil processing technologies were introduced, along with the increase in the quality and diversity of products obtained after the refining process. A world premiere in oil refining was introduced by Professor Suciu, who used steam for the thermal cracking process, at Teleajen refinery in 1939.

In 1938, the use of gas, air, or aerated mud as drilling fluid was tested, with different equipment, simultaneously in Romania and USA.

In 1939, 63 oil companies with a total capital of about 10 billion lei were operating in Romania. They had 17,200 employees comprising 338 engineers in drilling and production, plus 7,500 employees working in refineries. Figure 2 shows the distribution of capital in Romanian petroleum industry in 1938 (Calcan, 1997).

Around all the inter-war period, Romania constantly ranked $6^{\text {th }}$ worldwide in oil production. 
CBU INTERNATIONAL CONFERENCE ON INNOVATION, TECHNOLOGY TRANSFER AND EDUCATION

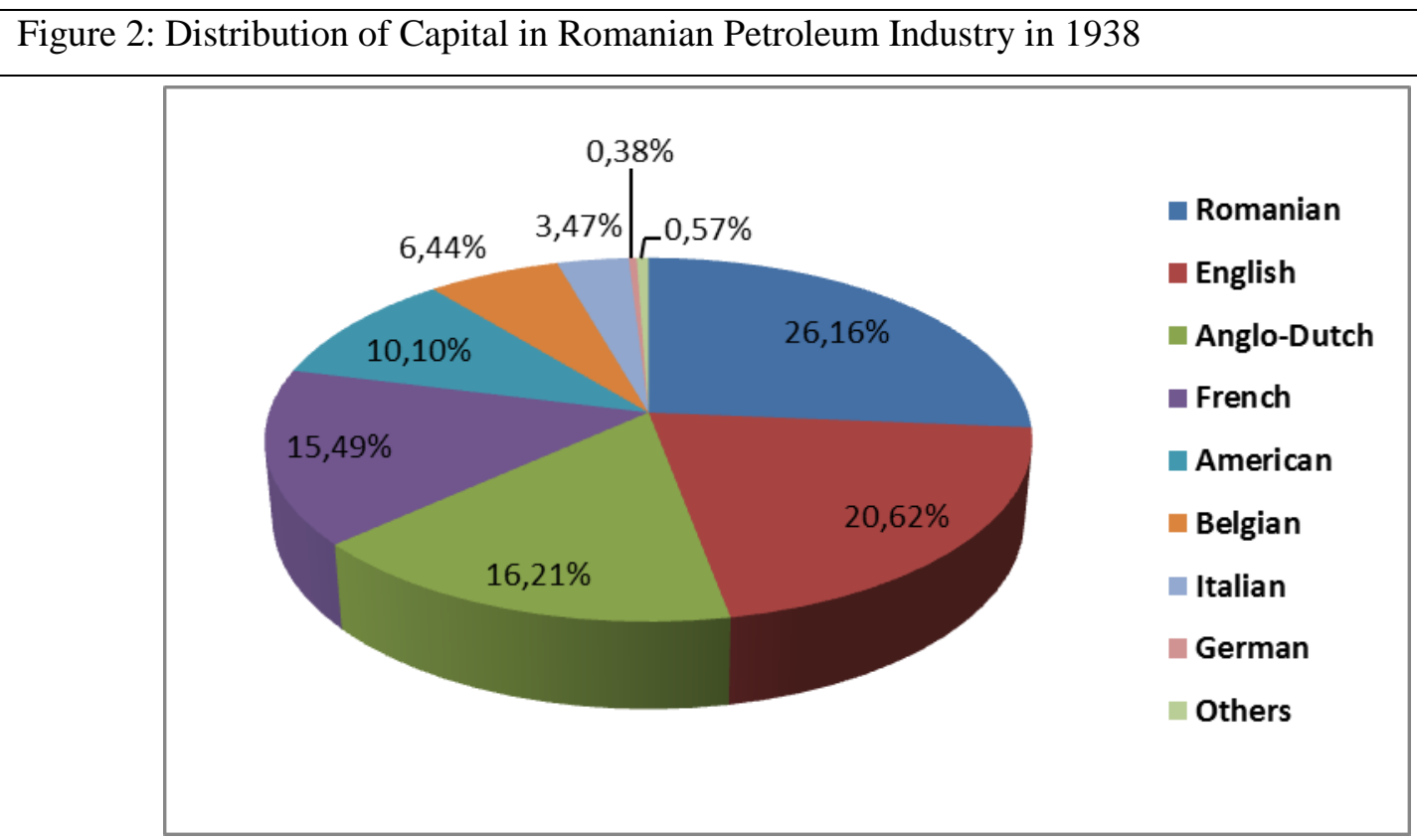

Source: Authors

Figure 3: Oil Production in Romania between 1857 and 2010

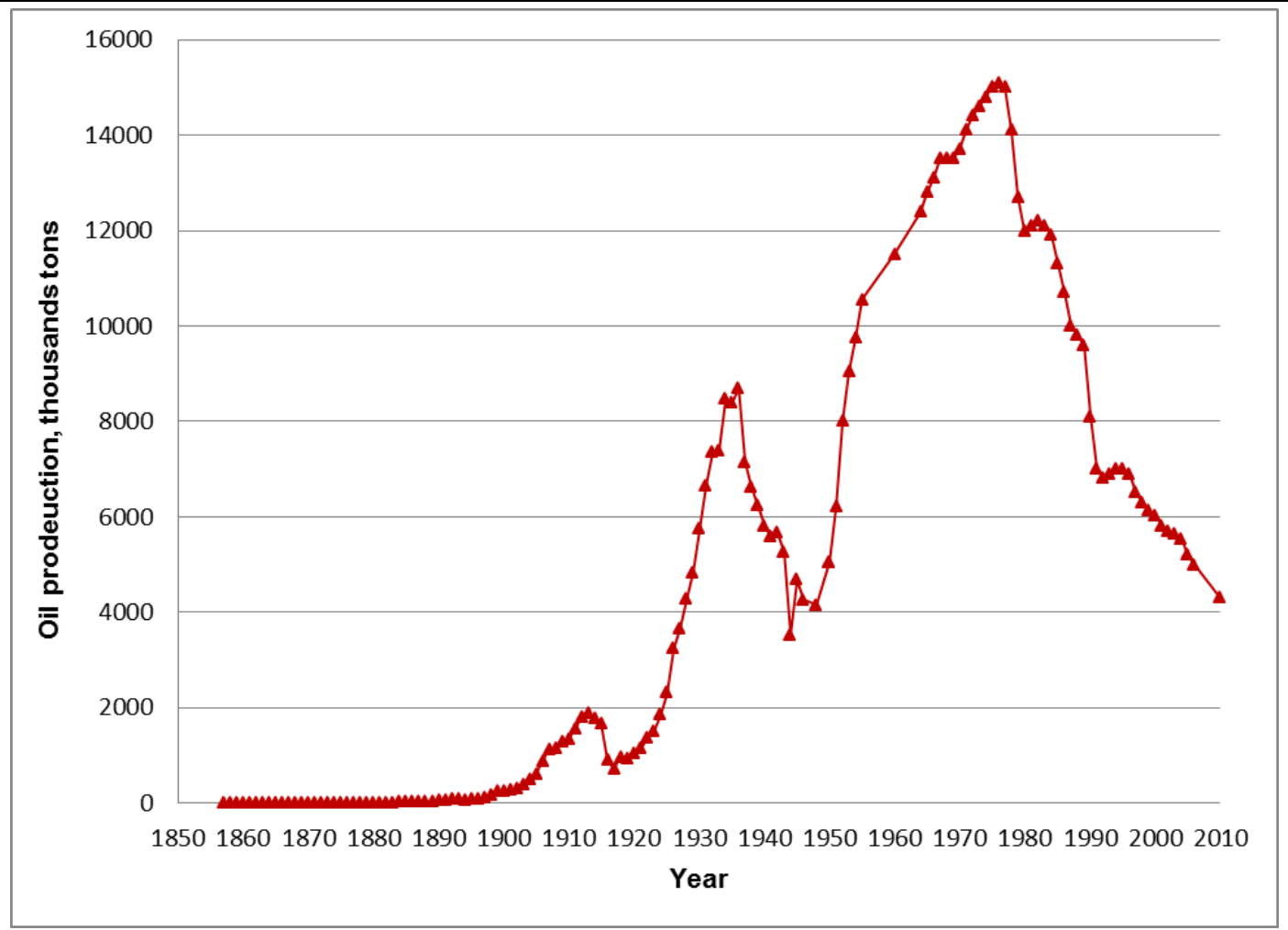

Source: Authors

During the 1940s, Dr. I. Basgan published over 50 articles, in Romania and other petroleum producing countries, as well as filed five patents in Romania and USA. At the same time, Eng. A. Drăgulescu brought about important technological contributions by introducing the drill- collars in well drilling, improving the drill bits, testing the electric log, and basing the secondary oil recovery by water and gas injection. 
The first pressure maintenance process in an oil reservoir by water injection started in 1943.

Between 1944 and 1974, 13,500 wells for petroleum prospecting and exploration were drilled, with a total length of 19 million meters.

In 1964, the in-situ combustion as a thermal method of oil recovery was initiated in Suplacu de Barcău; this process is still active today and has proven to be one of the most successful of its kind across the globe.

In 1968, the exploration for oil and gas on the continental platform in the Black Sea started. The first Romanian oil platform, built in the shipyard of Galaţi, was launched in 1975. One year later, the first Romanian off-shore oil well was drilled up to a depth of 5,006 meters, in a water depth of 86 meters.

In 1976, Romania achieved the greatest oil production (14.7 million tons), while the maximum natural gas production (39.37 billion cubic meters) was reported in 1986.

In 1987, the first submarine pipeline in Romania was put into operation, linking the Central Production Platform and the Midia petrochemical plant.

Between 1950 and 1989, the number of oil reservoirs in operation increased from 51 to 451.

In 1989, Romania had 16,000 oil wells and a production capacity of 9.2 million tons.

The evolution of the annual oil production in Romania between 1857 and 2010 is shown in Figure 3.

\section{Conclusion}

Permanent technical and scientific advancements achieved in Romania since the first crude oil pits to the off-shore fields today have contributed to the development of the world's oil industry. Many of the Romanian priorities in this domain have been achieved by precursors whose names have been forgotten and by other numerous anonymous individuals.

Although, in recent decades, the production of crude oil and natural gas in Romania has suffered a decline, the experience of Romanian petroleum specialists over a period of more than 150 years of industrial activity is employed by new generations of engineers, technicians, foremen, and workers both at home and abroad. Romanian researchers, professors, and teachers are preparing future technologies and future specialists to be able to utilize this valuable resource in the most efficient way.

\section{References}

Bălan, Şt. [Coordinator] (1979) Dicţionar cronologic al ştiinţei şi tehnicii universale [Chronological Dictionary of Universal Science and Technique]. Bucharest, Romania: Editura Ştiinţifică şi Enciclopedică

Boncu, M. C. (1971) Contribuţii la istoria petrolului românesc [Contributions to Romanian Petroleum History]. Bucharest, Romania: Editura Academiei.

Buzatu, Gh. (1981) România şi trusturile petrolifere internaţionale până în anul 1929 [Romania and the International Petroleum Trusts until 1929]. Iaşi, România: Editura Junimea.

Calcan, Gh. (1997) Industria petroliferă din România în perioada interbelică [Petroliferous Industry in Romania during the Interwar Period]. Bucharest, Romania: Editura Tehnică.

Demidov, A. N., \& Raffet, D. A. M. (1853). Travels in southern Russia and Crimeea; through Hungary, Wallachia, \& Moldavia, during the year 1837. London: J. Mitchell.

Gheorghiu, M., Neculau, T., Ionescu-Balea, E., \& Ştefănescu, I. (1972). Muzeul Republican al Petrolului - Ploieşti [National Petroleum Museum - Ploieşti]. [Guide]. Bucharest.

Giurescu, C. (1969). Vechimea exploatării petrolului şi a „,cerii de pământ" în ţările româneşti [Age of Petroleum and "Rock Wax" Production in Romanian Principalities]. Sibiu, Romania: Cibinium

Ionescu-Balea, E., \& Ştefănescu, I. (1977). Despre tehnica exploatării manuale a țiţeiului în ţara noastră. Aspecte legislative, economice şi sociale ale acestei activităţi [On the Technique of Manual Production of Crude Oil in our Country. Legislative, Economical and Social Aspects of this Activity]. Hronic prahovean, Ploieşti, Romania 
Ivănuş, Gh., Ştefănescu, I., Stirimin, Şt. N., Mocuţa, Şt. Tr., \& Coloja, M. P. (2004) Istoria petrolului în România [Petroleum History in Romania]. Bucharest, Romania: Editura AGIR

Mircea, I. (1968) Figuri de geologi români [Figures of Romanian Geologists]. Bucharest, Romania: Editura Ştiinţifică

Monitorul de Petrol Român [Romanian Petroleum Monitor] (1900), (1907), (1916), (1934).

Pop, M. D. (1961). Opere economice [Economical Works]. Bucharest, Romania: Editura Ştiinţifică

Popovici, V. (1957). Inceputurile exploatării capitaliste a petrolului în Moldova [Starts of Capitalist Petroleum Production in Moldavia]. Studii şi materiale de istorie modernă, Bucharest, Romania: Editura Academiei

Răvaş, Gh. (1957) Din istoria petrolului românesc [On Romanian Petroleum History]. Bucharest, Romania: ESPL

Romanian National Committee of World Energy Council (2013, November). Natural Gas Resources from Unconventional Fields - Potential and Recovery [Report]. Bucharest: Author.

Sédillot, R. (1979). Istoria petrolului [Petroleum History]. Bucharest, Romania: Editura Politică.

Statistics of Petroleum and Allied Substances (1938). The Science of Petroleum (Vol. 1), London: Oxford University Press.

Ştefănescu, I. (1998). Periplu în istoria petrolului românesc [Peregrination in Romanian Petroleum History]. Noua Revistă de Petrol, 1, 37

Teodorescu, V., \& Ştefănescu, I. (1968, August). Contribuţii arheologice la istoria petrolului român: cele mai vechi dovezi privind cunoaşterea şi folosirea materiilor petrolifere din ţara noastră [Archeological Contributions to Romanian Petroleum History: Oldest Evidences on Knowledge and Use of Petroleum Materials in our Country]. Petrol şi Gaze, 8, 519-520. 